\title{
The Village Financial Management System, A Policy Towards Independent Villages
}

\author{
Puji Handayati ${ }^{1}$, Mohd Rizal Palil ${ }^{2}$ \\ ${ }^{1}$ Faculty of Economics and Business, State University of Malang, Indonesia \\ ${ }^{2}$ Schools of Accounting, Universiti Kebangsaan Malaysia, Malaysia \\ E-mail: puji.handayati.fe@um.ac.id
}

Received: September, 2019; Accepted: February, 2019; Published: March, 2020

Permalink/DOI: http://dx.doi.org/10.17977/um002v12i12020p001

\begin{abstract}
The ultimate focus of this research is to find out how to improve the capabilities of the Village Apparatus and the preparation of the Guidance Book for IT-based Village Finance Administration towards Good Village Governance. Then, this research also focuses on mentoring activities in 15 villages in Gempol sub-district. Assistance results in 15 villages in Gempol Subdistrict, Pasuruan Regency, show that village financial management software can be applied properly. Assistance results in 15 villages in Gempol Subdistrict, Pasuruan Regency, show that village financial management software can be applied properly. Although there are still some difficulties in implementation due to the lack of skills of the village apparatus due to age and parameter constraints that need to be adjusted. In general, the software still needs to be refined related to the filling and storage stages that are still considered inefficient. On the other hand, a tutorial guide book that has been tested from several aspects is considered very adequate. The usefulness of the village financial management guide book is very helpful for beginners in applying village financial management software.
\end{abstract}

Keywords: Village Financial System, Village Financial Management, Independent Village, Village Finance Administration

JEL Classification: C3, E62, H5, $\mathrm{O4}$

\section{INTRODUCTION}

The existance of Law No. 6 of 2014 concerning villages brings its own opportunities and challenges. The opportunity to create a prosperous village is increasingly open due to the fact that this Law has regulated $10 \%$ of the state budget channeled to the village. With this budget, the village is given the authority to use the existing budget to realize a prosperous village. Like two sides of a coin, between expectations and challenges cannot be separated. The budget of $10 \%$ of the state budget is certainly not a small amount for rural development (Winarsi and Kristianti 2017; Wibisono et al. 2017). Therefore, the budget management and management is an inseparable challenge. Abusing potential or "CORRUPTION" will always be there. Learning from the previous experience, decentralization that gives "excessive" authority to the local level (grassroots) is considered as a hasty policy. Moreover, referring to scientists who are members of the International Crisis Group (ICG), the decentralization policy that was 
implemented in 1999 as "The Big Bang" began (Irawati: 2010; et al. 2018; (Desire 2014) ) Desire, 2014.). Of course, this new Village Law must be outside the black box of the errors of autonomy at the previous local level.

The Village Financial Management Guidelines, which are the implementing regulations of Law No. 32 of 2004 concerning Regional Government, state that village financial management is carried out by village officials, among others, the Village Treasurer and the Village Financial Management Technical Implementation (PTPKD). The results of the preliminary research that had been carried out where during the socialization of village financial management to 7500 head of village in East Java in 2014 found a picture that there was very little capacity of the village head and his apparatus in the management and administration of village finance at this time.

Village financial portraits are recorded in the form of APBDesa which should be managed in a transparent, accountable, participatory and orderly manner and budget discipline in accordance with the laws and regulations. $A P B D e s a$ as an instrument of public policy has an important and strategic role for the village government in carrying out government and implementing development in the framework of service to the community. APBDesa preparation as part of the village financial planning and budgeting process also has a strategic position in village financial management. The success of the village government in preparing the APBDesa is the first step to the success of the next village financial management stage. Therefore, a good understanding of the village budget policy is absolutely needed by the village apparatus as the implementer of village financial management (Makalalag et al., 2017; Kuncoro et al., 2012).

Referring to the results of the first year research conducted in Pasuruan Regency, problems that often arise related to the drafting of the APBDesa are caused by several factors, namely the weakness of human resources in understanding and implementing the APBDesa policy, the low skill of the village apparatus in using computers, and Village financial software designed by BPKP still does not accommodate detailed tax calculations that must be paid by the village treasurer.

The problem with most village governments that cannot compile the $A P B D e s a$ according to the budget cycle time schedule is more due to the factors of the scope of village government financial management and the village government financial planning and budgeting cycle. Both the financial management scope and the village government planning and budgeting cycle are not independent, but are tied to the scope of financial management and the supra village government planning and budgeting cycle. From the results of the study, the purpose of this study is how to improve the ability of the Village Apparatus and the preparation of the Book Tutorial Guide for IT-based Village Finance Administration towards Good Village Governance (Andry and Handrian 2017; Ojha and Pandey 2017).

\section{METHOD}

This study falls under the category of a research and development. The development research method contains three main component: (1) development models, (2) development procedures, and (3) product trials. This research and development model was adapted from the development model of (Pannen and 
Purwanto 2001; Haning, et al. 2018). The steps of this research are preliminary analysis, curriculum analysis, analysis of student characteristics, writing and preparation of teaching materials, product testing, revision, final products.

Data collection instruments were classified into two parts: (1) predevelopment data collection instruments and (2) post-development data collection instruments. The flow of research to be carried out is as follows:

a. The definition phase is carried out at the beginning of the study. At this stage, identification of village apparatus resources is spread in 10 villages in Gempol sub-district, Pasuruan regencies, the constraints faced in managing APBDesa.

b. Construction phase is the stage of completing the activities that will be carried out in improving the capability of the village apparatus that have been reviewed from stage 1 , as well as preliminary design of the table of contents of the village financial administration guide book by observing the process of the village financial system software created by BPKP. After the initial draft of the Village Finance Administration guide guide booklet was completed, expert judgment was carried out by competent experts in validity testing.

\section{Instrument Validation}

The instrument used in the validation is a questionnaire. This questionnaire uses a Likert scale (4 scales). The criteria for each rating scale are as follows:

a. Score 4 if it is very good / very interesting / very clear / very easy / very appropriate / very feasible

b. Score 3 if it is good / interesting / clear / easy / appropriate

c. Score 2 if not good / not interesting / not clear / not easy / inappropriate / not feasible

d. Score 1 if it is not good / very unattractive / very unclear / very not easy / very inappropriate.

The questionnaire used as an instrument in the validation of the tutorial book also contains a comment section and suggestions from the validator as the material for the next revision.

\section{Data Analysis Technique}

For qualitative data, the analysis carried out is an analysis of suggestions, responses, and criticisms from the validator, while for quantitative data analysis used percentage analysis techniques, with the formula:

Whereby,

$$
P=\frac{\sum x}{\sum x 1} \cdot 100 \%
$$

$$
\begin{array}{ll}
\mathrm{P} & =\text { Percentage } \\
\sum \mathrm{x} & =\text { Number of answers of all respondents in } 1 \text { item } \\
\sum \mathrm{x} 1 & =\text { Number of ideal answers in } 1 \text { item }
\end{array}
$$

After being analyzed, to determine the conclusion of each item that is validated, the following criteria are applied: 
Table 1. Validation Criteria

\begin{tabular}{cc}
\hline ANSWER & CRITERIA \\
\hline $80-100$ & Valid \\
$60-79$ & Quite Valid \\
$40-59$ & Less Valid \\
$0-39$ & Not Valid \\
\hline
\end{tabular}

\section{RESULTS AND DISCUSSION}

The research on Soft-ware development of Village Financial Management towards Good Village Governance in the second year focuses on two main activities that are mentoring the implementation of village financial software that has been developed in the first year and creating a village financial management tutorial guide book. Before making the initial activity, the activities carried out were to disseminate the village financial software to village officials in 15 villages in Gempol subdistrict of Pasuruan Regency.

A description of the mentoring report in 15 villages in Gempol Subdistrict by each facilitator will be presented in detail in the following sub-topics:

\section{Wonosuryo}

Overall, the Wonosunyo Village Treasurer stated that it was greatly helped by the Village Financial System application, even though there were some technical things such as the incompatibility of application parameters with the village conditions and the need for the Village Treasurer to understand more about Village Financial System which are still new things.

\section{Wonosari}

Village Financial System of Wonosari Village Operators are held by the Village Secretary, this is due to the lack of human resources which makes the Village Secretary have to be concurrently in charge. Even so, Village Financial System can run well and without problems because the early application of Village Financial System has begun in 2016 so that it is not new to the Wono-sari Village device.

\section{Sumbersuko}

As in Wonosari Village, Sumbersuko Village gives Village Financial System operator assignments not to the Village Treasurer but this is not a problem if Village Financial System can be operated properly. Village Financial System operators complain that the training provided is less than optimal so that there are various things that are not well understood.

\section{Ngerong}

The implementation of Village Financial System in Ngerong Village can run well, this is conveyed by Operatos Village Financial System if the problems that occur can be resolved and when this study Ngerong Village has arrived at the completion stage of SPJ.

\section{Kepulungan}

Like Ngerong Village, Kepulungan Village can implement Village Financial System well. The Village Secretary said that if human resources in Kepulungan 
Village have sufficient capacity to overcome various obstacles related to village financial management.

\section{Randupitu}

The Village Treasurer who is also the Village Financial System operator can implement Village Financial System well, where when the assistance is carried out, the Village has issued semester 1 SPJ.

\section{Kejapanan}

The parameter problems that do not suit the needs of the village are one of the obstacles experienced by the Kejapanan Village Financial System Operator. Village Financial System operators are not able to understand the implementation of education systems so that there is a need for ongoing mentoring and training.

\section{Carat}

Village Financial System of Carat Village operators complained about the parameters that were less specific and Village Financial System who were less flexible with village needs. This happens because there is a lack of adaptation to the system so that the village has not been able to carry out the implementation properly according to the needs of the village.

\section{Watukosek}

Some technical constraints conveyed by the Village Treasurer related to parameters that are not in accordance with the Village. In addition, there were several obstacles related to budgeting and administration of village finance in the implementation of Village Financial System.

\section{Karangrejo}

As in other villages, several technical issues related to village finance administration were experienced by the Karangrejo Village Treasurer. However, this was conveyed if due to human error and lack of village treasurer in understanding the system.

\section{Bulusari}

The treasurer of Bulusari Village complained that Village Financial System were less efficient because the system could not automatically change when there was a change in nominal data. In addition, a number of technical constraints occurred when the initial data input to Village Financial System began.

\section{Jerukpurut}

Unlike the other villages, Jerukpurut Village has not absorbed Village Financial System. The Village Treasurer revealed that there was no coordination with the village superintendents so that the Village did not have Village Financial System software yet.

\section{Winong}

The Village Treasurer of Winong revealed that if there were no serious obstacles in operating Village Financial System. Furthermore, he revealed that with Village 
Financial System the process of village financial management becomes more efficient.

\section{Legok}

Problems related to parameters that are not in accordance with the Village are also one of the problems in Legok Village. Another obstacle faced was the difficulty of Village Financial System Operators in the implementation of village financial management systems.

\section{Gempol}

Some obstacles related to village financial management can be handled well by Gempol Village. Then the Village Financial System Operator of Gempol Village explained that Village Financial System were very helpful, effective and efficient.

Products developed in the form of Village Financial Management tutorial books. Based on the results of the product trials, it was obtained a mean of 4.42 from a scale of 5 and a percentage of 88.56 which indicated that the guidebook was very valid. The average values and percentages are obtained based on the assessment of: (1) aspects of the contents of the content, (2) aspects of presentation feasibility, (3) aspects of language feasibility, and (4) aspects of the feasibility of graphics.

From the feasibility aspect, the contents of the guidebook were obtained with a mean of 4.14 and a percentage of 82.86 which showed a valid guidebook. Based on quantitative and qualitative data validation of the feasibility aspects of the contents of the guidebook, the revision is done by (1) labeling each model that has been analyzed, the model used exercises analysis, concept conclusions, and training in a concrete manner so that there is no difference in understanding with the reader.

From the aspect of feasibility the presentation of the guidebook is obtained with a mean of 4.41 and a percentage of 88.23 which shows the manual is very valid. Based on quantitative and qualitative data validation aspects of the content of the guidebook, revisions are made by: (1) giving a list of references to the images used, (2) completing the list of available sources, (3) detailing the table of contents, (4) improving the appearance of pages. ii and iii, (5) replacing the title that describes the contents of the section and and (5) improving the appearance of the photo.

From the aspect of language feasibility the guidebook was obtained with a mean of 3.95 and the percentage of 78.93 which showed the teaching material was very valid. Based on quantitative and qualitative data validation aspects of the guideline, the revision is done by (1) replacing the subtitles on the parts of teaching materials, (2) changing the term "edition" to refer to the chapters of teaching materials, (3) the concept map is made more complete by presenting the critical thinking skills developed, and (4) the titles in this teaching material are replaced (Hehamahua, 2015; Veljković, et al 2014; Schmidthuber, et al 2017; Mondale et al. 2017).

From the feasibility aspect, the graphic material of teaching material is obtained with a mean of 4.38 and the percentage of 87.81 which shows the teaching material is very valid. Based on quantitative and qualitative data validation 
aspects of the guideline feasibility, the revisions were carried out by: (1) changing the picture in the guidebook, (2) correcting the cover, (3) changing the font size in the title and subtitle, (4) improving the appearance on page ii and iii , and (5) change the color in parts of the guidebook.

\section{CONCLUSION}

The results of mentoring in 15 villages in Gempol Subdistrict Pasuruan Regency showed that the village financial management software (Siskuedes) could be applied properly. Although there are still some difficulties in implementation because of various factors, the skills of the village apparatus are still lacking due to age, lack of training, and so on. In addition, in terms of technical constraints, the parameters need to be adjusted to each village's topography.

In general, the software still needs to be refined related to the filling and storage stages that are still considered inefficient. On the other hand, a tutorial guide book that has been tested from several aspects is considered very adequate. The usefulness of village financial management manuals is very helpful for beginners in applying village financial management software.

\section{ACKNOWLEDGEMENT}

This paper was supported by the DRPM Ministry of Research, Technology and Higher Education Indonesia; LP2M and Faculty of Economics and Business, State University of Malang (Universitas Negeri Malang) Indonesia and Universiti Kebangsaan Malaysia, Malaysia.

\section{REFERENCES}

Abdullah, Hayat. 2015. "Human Capital Dan Pembangunan Infrastruktur Terhadap Pertumbuhan Ekonomi Dan Kesejahteraan Masyarakat Reallocation Fiskal Policy : Implications For Enhancing Human Capital And Infrastructure Development On Economic Growth And Welfare Society," 117-28.

Arsana, I. M.M., and I. N. Sugiarta. 2018. "Effective Model Development of Internal Auditors in the Village Financial Institution." Journal of Physics: Conference Series 953 (1): $0-6 . \quad$ https://doi.org/10.1088/17426596/953/1/012093.

Azlina, Nur, Amir Hasan, Desmiyawati, and Iskandar Muda. 2017. "The Effectiveness of Village Fund Management (Case Study at Villages in Coastal Areas in Riau)." International Journal of Economic Research 14 (12): 325-36.

Bawono, Andy Dwi Bayu, Heppy Purbasari, and Suyatmin Waskito Adi. 2019. "Financial Management Reform Process in the Indonesian Village Government." Humanities and Social Sciences Reviews 7 (4): 962-67. https://doi.org/10.18510/hssr.2019.74131.

Bustaman, Bustaman, Erlisa Amalia, and Jalaluddin Jalaluddin. 2018. "A Performance Analysis of Village Fund Management: A Case Study in Lut Tawar District - Indonesia." Journal of Accounting Research, Organization and Economics 1 (2): 112-21. https://doi.org/10.24815/jaroe.v1

Desire, Legal. 2014. "The Centre for Transparency and Accountability in Governance." Journal of Transparency and Accountability in Governance: 
Call for Papers vol.9 edit.

Diamantina, Amalia. 2017. "Management, Distribution, and Redemption of Village Fund." Diponegoro Law Review 2 (1): 203. https://doi.org/10.14710/dilrev.2.1.2017.203-226.

Ekonomi, Jurnal, Keuangan Akreditasi No, Departemen Akuntansi, Fakultas Ekonomi, and Bisnis Universitas Airlangga. 2014. "Strategi Implementasi Aplikasi Sistem Keuangan Desa:" no. 80: 468-89. https://doi.org/10.24034/j25485024.y2018.v2.i4.4019.

Fikri, Haidar, Didik Gunawan Suharto, and Rino Ardhian Nugroho. 2018. "International Journal of Multicultural and Multireligious Understanding Utilization of Electronic Government in Realizing Transparency and Accountability of Village Government: Synergy of Implementation of Electronic Village Budgeting and Electronic Moni." International Journal of Multicultural and Multireligious Understanding (IJMMU) 5 (4): 453-69. https://doi.org/10.18415/ijmmu.v5i4.425.

Handrian, H. Andry and E. 2017. "Implementation Of E-Government In Transparency Regional Financial Management" 163.

Handayati, P, and D Djuliardi. 2018. "Developing Software for Village Financial Management." KnE Social Sciences 3 (10): 261-73. https://doi.org/10.18502/kss.v3i10.3379.

Kuncoro, Mudrajad. 2012. "Perencanaan Daerah." In , 222. Jakarta: Salemba Empat.

Kwiatek, Piotr. 2018. "International Journal of Applied Business \& International Management P-ISSN: 2614-7432 ; E-ISSN: 2621-2862” 3 (2): 39-56.

Karmawan, Mr. 2018. "Role and Contribution of Village Financial Management to Realize Transparency And Accountable Village Budgeting Revenue And Expenditure District of West Bangka" 46 (Ebic 2017): 293-99. https://doi.org/10.2991/ebic-17.2018.46.

L. Schmidthuber, D. Hilgers, T. Gegenhuber, and S. Etzelstorfer. 2017. "The Emergence of Local Open Government: Determinants of Citizen Participation in Online Service Reporting" 34: 457-469.

Makalalag, Astri Juanita, Grace B Nangoi, and Herman Karamoy. 2017. "Akuntabilitas Pengelolaan Dana Desa Di Kecamatan Kotamobagu Selatan Kota Kotamobagu." Jurnal Riset Akuntansi Dan Auditing "Goodwill” 8 (1): 149-58. https://ejournal.unsrat.ac.id/index.php/goodwill/article/view/15334.

Miles, Matthew B. and A. Michael Huberman. 1992. Analisis Data Kualitatif: Buku Sumber Tentang Metode-Metode Baru. Edited by (Diterjemahkan oleh Tjetjep Rohendi Rohidi). Jakarta: Universitas Indonesia Press (UI- Press).

Nazir, Yendri. 2017. "Governance in Financial Management of Villages in Kepulauan Meranti Regency" 163 (Icodag): 341-45. https://doi.org/10.2991/icodag-17.2017.66.

Niswah, Fitrotun, Goinpeace Handerson Tumbel, and Aslinda. 2018. "Village Finance System (SISKEUDES): Transparency of Village Asset Management toward Open Government Partnership." Proceedings of the 1St International Conference on Social Sciences (Icss 2018) 226 (Icss): 163-68.

Nurcholis, Hanif. 2011. Pertumbuhan Dan Penyelenggaraan Pemerintah Desa. Jakarta: Erlangga. 
Nurhakim, Irman, and Ivan Yudianto. 2018. "Implementation of Village Fund Management" 1 (2): 39-55.

N. Veljković, S. Bogdanović-Dinić, and L. Stoimenov. 2014. "Benchmarking Open Government: An Open Data Perspective" 31: 278-290.

Ojha, Shashank, and I. M. Pandey. 2017. "Management and Financing of EGovernment Projects in India: Does Financing Strategy Add Value?" IIMB $\begin{array}{llll}\text { Management } & \text { Review } & 29 & \text { (2): }\end{array}$ https://doi.org/10.1016/j.iimb.2017.04.002.

Peraturan Menteri Dalam Negeri No. 39 Tahun 2010 tentang Badan Usaha Milik Desa (BUMDes)

Peraturan Menteri Desa PDTT No. 4 Tahun 2015 Tentang Pendirian, Pengurusan, Pengelolaan dan Pembubaran Badan Usaha Milik Desa

Peraturan Pemerintah No.72 Tahun 2005 tentang Desa

Rangkuti, Freddy. 2008. The Power Of Brands. Jakarta: Gramedia.

Setyadi. 2003. Bumdes Sebagai Alternatif Lembaga Keuangan Desa. Yogyakarta: UPP STM YKPN.

Seviola Islaini, Lalu Husni, and M. Ilwan. 2019. "The Auhtority of the Audit Board of The Republic Of Indonesia in Carrying Out Audits of Village Financial Management." International Journal of Scientific Research and Management 7 (10): 191-99. https://doi.org/10.18535/ijsrm/v7i10.1la01.

Soemantri, Roebiandini, Memed Sueb, and Yusar Yusar Sagara. 2019. "Financial Management For Cipacing Village Apparatus." Proceeding of Community Development 2: 618. https://doi.org/10.30874/comdev.2018.305.

Tahili, Mohamad Thahir Haning; Mashuri H. 2018. "Strengthening the Capacity of Village Government in the Implementation of Village Fund Policy at Maros Regency of South Sulawesi Province." Advances in Social Science, Education and Humanities Research 191: 383-91.

Taufiqurokhman Taufiqurokhman, and Andriansyah Andriansyah. 2018. "Implementation of Allocation of Village Funds (ADD) Increases Institutional and Ngombakan Village Development Programs Manifest Good Governance." Matra Pembaruan 2 (3): 197-206. https://doi.org/10.21787/mp.2.3.2018.197-206.

Undang-Undang No.32 Tahun 2004 tentang Pemerintahan Daerah

Undang-Undang No .6 Tahun 2014 tentang Pemerintahan Desa

Wana Mariska. 2018. "The Effect of Competence, Commitment, and Regulation on the Accountability of Village Financial Management With Moderated Spirituality." International Journal of Advanced Research 6 (8): 455-62. https://doi.org/10.21474/ijar01/7542.

Winarsi, Sri, and Dwi Kristianti. 2018. "Village Fund Management in the Perspective of State Finances for the Purpose of Rural Community Empowerment" 131 (72): 277-81. https://doi.org/10.2991/iclgg-17.2018.36.

Yuliana, Yuliana, Cut Rahmawati, Yulfrita Adamy, Edwar Edwar, and Azlim Azlim. 2018. "The Effectiveness Analysis of Village Funds Management Planning." Proceedings of AICS-Social Sciences, no. 113: 37-43.

Yulianti, Yulianti, Dyah N.A. Janie, and Sudarman Sudarman. 2019. "Village Financial System: How Do the Village Government Officials Understand the System?” International Journal of Human Resource Studies 9 (1): 330. https://doi.org/10.5296/ijhrs.v9i1.14231. 